\title{
Maori Language
}

National Cancer Institute

\section{Source}

National Cancer Institute. Maori Language. NCI Thesaurus. Code C154036.

An Eastern Polynesian language spoken by the Maori people of New Zealand. 